\title{
Right Heart Pressures in Acute Myocardial Infarction
}

\author{
D. C. FLUCK, P. A. VALENTINE, B. TREISTER, B. HIGGS, D. N. REID, R. E. STEINER, \\ AND J. P. D. MOUNSEY
}

From the Departments of Medicine and Radiology and the M.R.C. Cardiovascular Group, the Royal Postgraduate Medical School, London W.12

The hæmodynamic changes in the pulmonary circulation following acute myocardial infarction are complex and incompletely understood. In order to obtain a clearer picture of these and so help to develop a more rational form of therapy, serial measurements of pulmonary arterial and right ventricular pressures have been made in patients with a recent cardiac infarct. The float right heart catheter has proved so useful in monitoring progress, especially in relation to therapy with diuretics, etc., that we now use it more or less routinely in all acutely ill patients with cardiac infarction. Changes in right heart pressures have been examined in relation to the general clinical picture, chest $x$-ray appearances, arterial oxygen tension, systemic blood pressure, and cardiac output.

\section{SubJects AND Methods}

Twenty-six consecutive patients admitted to the Intensive Coronary Care Unit at Hammersmith Hospital within $\mathbf{4 8}$ hours of the onset of an acute myocardial infarction were examined in three ways. The diagnosis was based on a typical history of prolonged cardiac pain, together with pathognomonic serial electrocardiographic changes ( $Q$ wave, $S-T$ segment, and $T$ wave changes) or changes suggestive of infarction ( $T$ wave changes or bundle-branch block) associated with a transient rise in lactic dehydrogenase enzyme (over 250 units, with over $50 \%$ heat stable).

The average age of the patients was 59 years, with a range of 40 to 87 . There were 22 men and 4 women. Nineteen of the patients were admitted with their first infarct, but 8 of these had previously suffered from angina. The remaining 7 patients had had one or more infarcts previously. One patient was studied during two successive infarcts. Six patients were known to have had hypertension before the infarct. Two had

Received January 21, 1967. associated chronic bronchitis and one had trivial rheumatic mitral incompetence. None had diabetes mellitus. Five patients died and in each case necropsy confirmed the presence of a recent cardiac infarct.

Studies were made on 27 episodes of infarction, including 2 infarcts in 1 patient. Of the infarcts, 20 were anterior, 6 were posterior, and in 1 the site was uncertain, being obscured by the presence of left bundle-branch block.

Pressure Measurements. Right heart pressures were measured through fine polyethylene (PE60) tubing cut to a length of $100 \mathrm{~cm}$. The PE60 catheter was introduced percutaneously into an antecubital vein by the Seldinger technique (1953) and the tip floated into the right ventricle or pulmonary artery under pressure control. Occasional extrasystoles were noted as the tip of the catheter passed through the right ventricle, but no other arrhythmia occurred. The catheter tip was left either in the right atrium or in the pulmonary artery for up to 9 days, and a litre of 5 per cent dextrose containing 10,000 units of heparin was slowly dripped through the tubing over each 24 hours. Leaving this catheter in place for up to 9 days did not give rise to complications.

A Statham P23Gb transducer was used. The system as a whole had a resonant frequency of $30 \mathrm{c}$./sec. Pressures were recorded on a Devices 4-channel direct writer.

Pressures were measured in the horizontal position in 23 patients, the zero being taken as $5 \mathrm{~cm}$. below the sternal angle. In the other 3 patients the pressures were recorded with the patient propped up at about $20^{\circ}$, the zero again being taken as $5 \mathrm{~cm}$. below the sternal angle.

Right heart pressures (either right ventricular and/or pulmonary arterial pressure) were first measured on the day of the infarct in 24 cases and on the second day in the other 3 infarcts. Serial records of pressure were made daily as far as possible for 2 to 9 days with an average of 5 days. In general, measurements were discontinued a day or so after the pressures appeared to 748 
special hæmodynamic problems, further pressure measurements were made after the first 9 days, on the 21 st and 24th day of the infarct respectively, the PE60 catheter being reintroduced into the right heart.

All but one of the patients were receiving oxygen by an M.C. face mask at $61 . / \mathrm{min}$. for the first 3 to 4 days. In the other patient all the pressures were recorded when breathing air. In one patient, with a raised pulmonary arterial pressure, changes in pressure on breathing oxygen and air were studied.

Chest Radiographs. During the first 5 days portable chest $x$-ray films (lateral and antero-posterior films) were taken daily; thereafter they were repeated at approximately weekly intervals. The serial $x$-ray films were taken at a standard distance of $\mathbf{4}$ feet and as far as possible with comparable penetration in each patient. The chest $x$-ray pictures were reported by one of us (R.E.S.) independently of the clinical findings.

Radiological signs indicative of interstitial pulmonary œdema were septal lines, perihilar haze, and perivascular and peribronchial cuffing: widespread shadowing of more or less uniform density and somewhat ill-defined margins indicated intra-alveolar pulmonary œdema (Gleason and Steiner, 1966).

Arterial Blood Gases. In 19 patients, one of whom was studied during 2 successive infarcts, arterial blood was obtained by brachial arterial puncture, care being taken to induce good local anæsthesia. The arterial blood samples were withdrawn with the patient breathing air and were collected daily for the first 3 to 8 days, and, thereafter, at about weekly intervals until discharge from hospital.

All blood samples were immediately immersed in ice and analysed within one hour of collection.

The $\mathrm{O}_{2}$ and $\mathrm{CO}_{2}$ tensions of the blood were measured by a polarographic electrode (Instrumentation Laboratory IL 113) whose accuracy was checked against a tonometrically calibrated electrode analyser. The $p H$ of blood was measured by the same instrument.

Cardiac Output. In 7 patients the cardiac output was calculated by the direct Fick principle. The oxygen consumption was measured by collecting expired air in a Douglas bag, a period of acclimatization of at least 5 minutes being allowed before the collection was begun. The $\mathrm{O}_{2}$ and $\mathrm{CO}_{2}$ tension of the expired air was measured by the polarographic electrode and the volume was measured by passing it through a dry gas meter. Arterial blood was obtained from the brachial artery and the mixed venous blood from the pulmonary artery or right ventricle. The $\mathrm{O}_{2}$ content of the arterial and mixed venous blood was calculated from the $\mathrm{Po}_{2}, \mathrm{pH}$, and $\mathrm{Hb}$ concentration, using Dill's oxygen dissociation tables.

The cardiac output was first measured within 24 hours of the onset of the infarct in 6 of the 7 patients and within 36 hours in the seventh. Serial measurements were then made in the following 3 to 6 days. In 3 of the 7 patients the cardiac output was again measured at from 11 to 24 days after the infarct.
Clinical Features. Routine records were kept of heart rate and blood pressure. The respiratory rate was observed under resting conditions by one of us (B.T.). Special attention was given to the presence of basal crepitations in the lungs. A third or a fourth heart sound was carefully looked for and recorded in the phonocardiogram.

\section{Results}

Right Heart Pressure. A raised systolic pulmonary arterial pressure (above $30 \mathrm{~mm}$. $\mathrm{Hg}$ ) was found in 21 out of 27 episodes of acute myocardial infarction (Fig. 1). In those instances where the catheter was in the pulmonary artery rather than in the right ventricle, a parallel rise in diastolic and mean pulmonary arterial pressure was found (Fig. 1). Serial measurements were made in 25 episodes of infarction. During the first week, 22 showed a clear fall of pressure (Fig. 2), the final measurement in each case being within normal limits. In 3 other patients the pulmonary arterial pressure remained above normal at the time of the final measurement and these were clinically in chronic left ventricular failure. One patient who was studied after 2 successive infarcts showed a transient rise in pulmonary arterial pressure with each attack (Fig. 3). Apart from the over-all variations in pulmonary arterial pressure in relation to the clinical course of the acute cardiac infarct, other physiological factors caused temporary changes in pressure. In one patient, events such as micturition, vomiting, and defæcation, were found to cause a large rise in pulmonary arterial pressure of $15-20 \mathrm{~mm}$. Hg mean, which took several minutes to return to more normal levels (Fig. 4).

The right ventricular end-diastolic pressure was above $5 \mathrm{~mm}$. $\mathrm{Hg}$ initially (on first or second day) in 12 of the 23 patients in whom it was measured, ranging from $6-18 \mathrm{~mm}$. $\mathrm{Hg}$. Serial measurements of right ventricular end-diastolic pressure were made in 13 patients (Fig. 5). In all 6 of the 13 patients whose right ventricular end-diastolic pressure was raised to between $6-18 \mathrm{~mm}$. $\mathrm{Hg}$ initially, a fall to normal was observed (Fig. 6). Of the other 7 patients, whose initial right ventricular end-diastolic pressure was not above $5 \mathrm{~mm}$. $\mathrm{Hg}, 6$ showed a small fall of up to $5 \mathrm{~mm}$. $\mathrm{Hg}$, whereas the seventh showed a small rise.

Systemic Blood Pressure. Serial measurements of systemic blood pressure did not show a consistent pattern. In 12 cases the systemic blood pressure was within the normal range on admission and showed little change during the acute illness. In 7 cases the blood pressure fell below $100 \mathrm{~mm}$. $\mathrm{Hg}$ systolic within the first 48 hours. The hypotension 


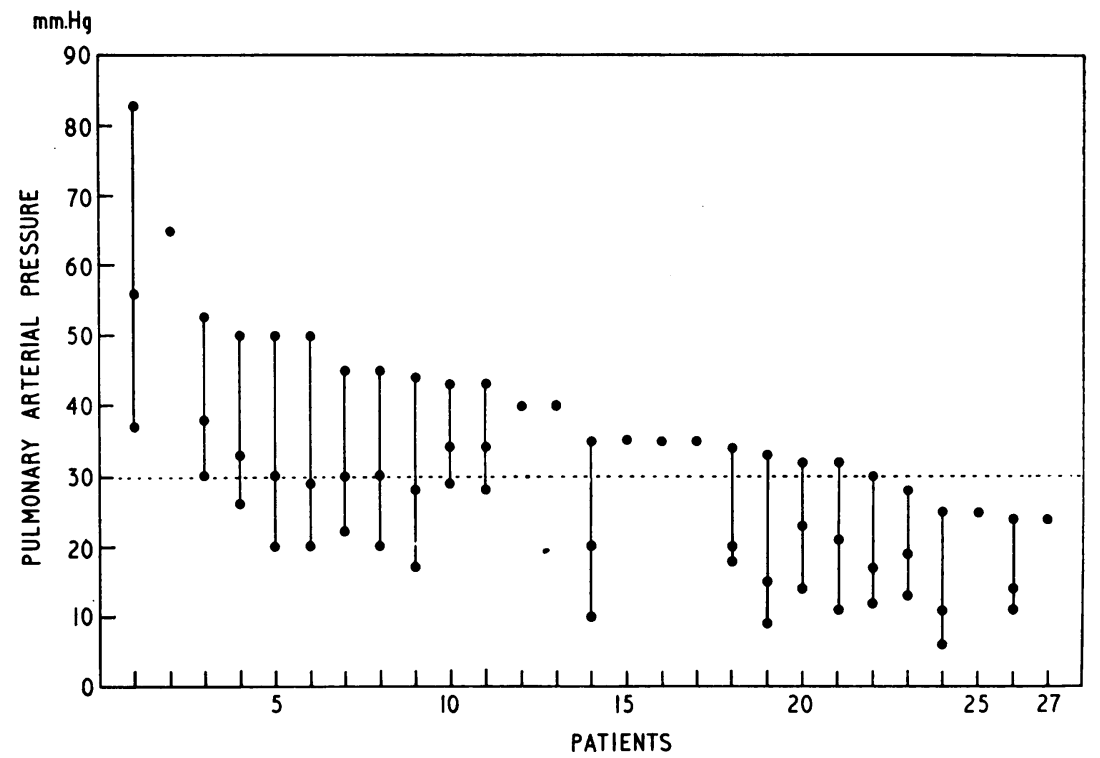

Fig. 1.-Pulmonary arterial systolic pressure in 27 episodes of acute myocardial infarction, when first meassured within 48 hours of the onset of infarction. Pulmonary arterial diastolic and mean pressures are also shown, where the pulmonary artery was catheterized as well as the right ventricle.

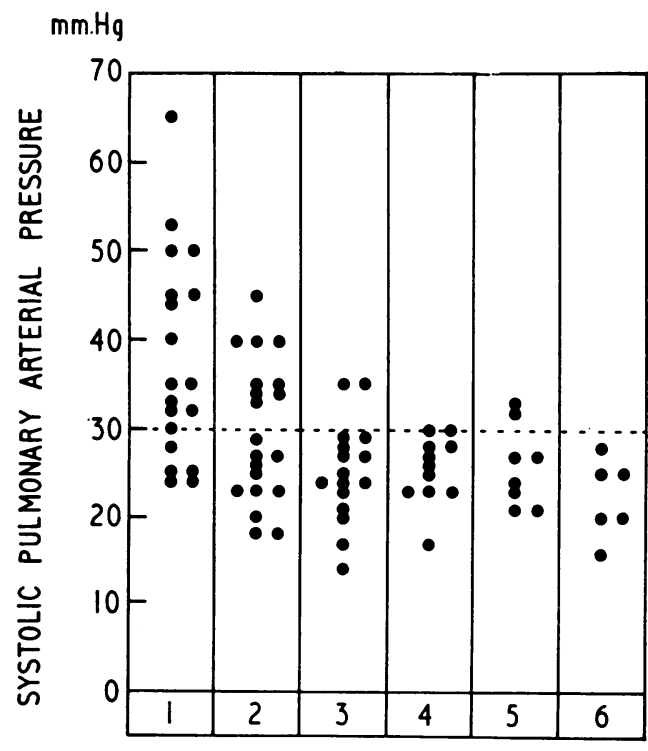

DAYS AFTER INFARCT

FIG. 2.-Serial measurements of pulmonary arterial systolic pressure in 22 episodes of acute myocardial infarction over the first 6 days after the infarct. Pressures were usually recorded daily until they returned to normal. (Three patients with chronic left ventricular failure and persistent left ventricular hypertension were excluded from this chart. Two other patients of the original 27 episodes died within the first 48 hours, and are therefore also excluded.) in 3 of them was associated with sinus bradycardia and vasovagal episodes, whereas in the other 4 there was sinus tachycardia with clinical evidence of left ventricular failure.

Eight patients had systemic hypertension on admission, the lowest pressure being $170 / 100 \mathrm{~mm}$. Hg. Four of these were known to have had a raised systemic blood pressure before the infarct, but in the other 4 no information about their previous pressure was available. In 7 of these patients the systemic blood pressure fell to normal levels over the first few days, but in the eighth hypertension persisted.

Chest Radiographs. In 9 of the 27 episodes of infarction radiological evidence of pulmonary œdema was seen (Fig. 7). In 7 patients there was evidence of intra-alveolar œdema, while in the remaining 2 the œdema was interstitial only. In all but 1 patient, who died within 36 hours, the pulmonary odema completely cleared during the first week.

Arterial Oxygen Tension. The arterial $\mathrm{O}_{2}$ tension was reduced below $80 \mathrm{~mm}$. $\mathrm{Hg}$, at some stage during the first week after the infarct, in 19 of the 20 episodes of infarction in which it was measured (Fig. 8). In none, however, did it fall below $45 \mathrm{~mm}$. $\mathrm{Hg}$ and in only 7 cases was it ever below $60 \mathrm{~mm} \mathrm{Hg}$. 


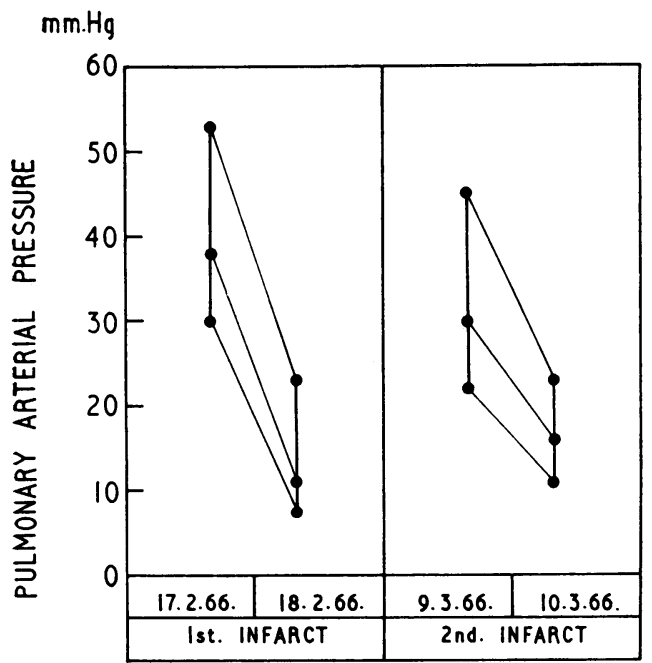

FIG. 3.-Changes in pulmonary arterial pressure during 2 successive episodes of acute myocardial infarction in the same patient. On each occasion the pressure was raised on the first day of the infarct and fell to normal the following day.

$\mathrm{mm} . \mathrm{Hg}$.

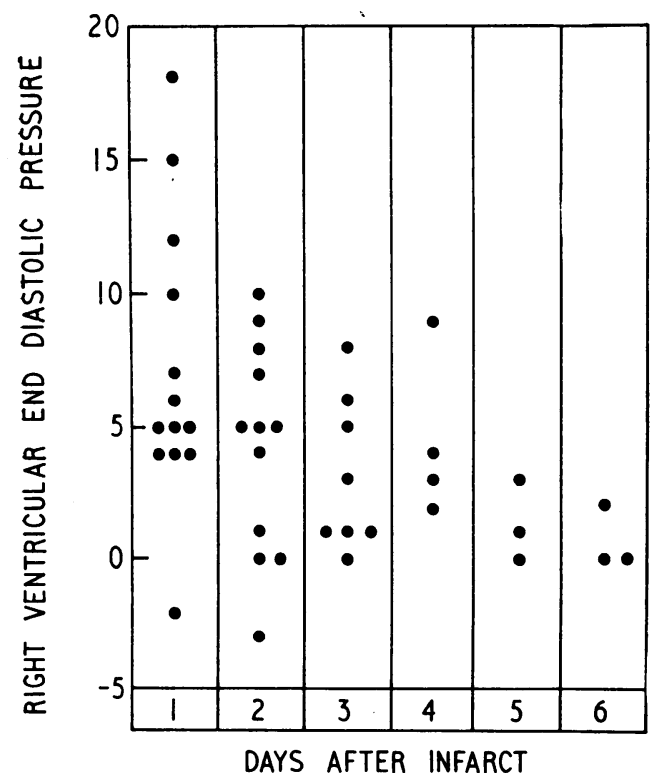

FIG. 5.-Serial measurements of right ventricular end-diastolic pressure in 13 episodes of acute myocardial infarction over the first 6 days after the infarct. Pressures were usually recorded daily until they returned to normal.

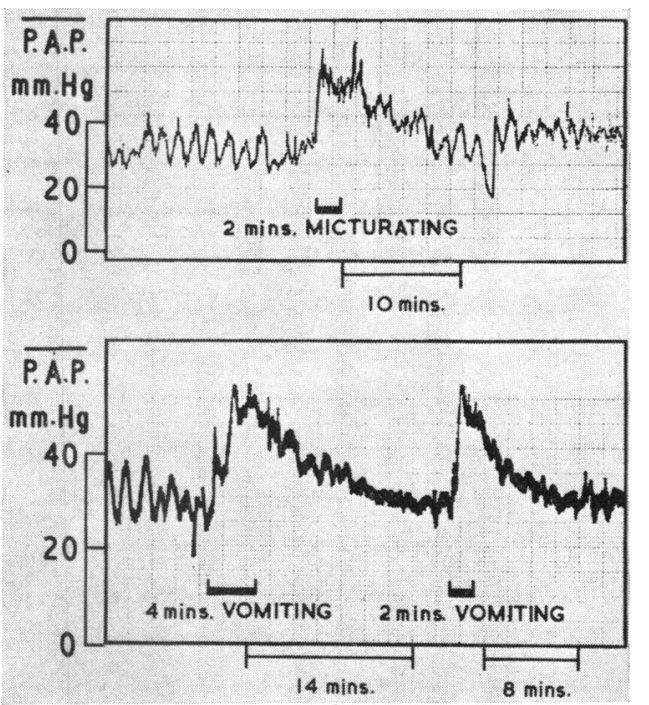

FIG. 4.-Effect of micturition and of vomiting on the pulmonary arterial mean pressure in Case 7 in chronic left ventricular failure. Prolonged rise in pulmonary arterial pressure, lasting between 8 and 14 minutes followed these events. The smaller and more rapid phasic changes in pulmonary arterial pressure accompanied Cheyne-Stokes respiration in this patient, a rise in pressure being associated with the hyperpnœic phase (Fluck et al., 1967a).

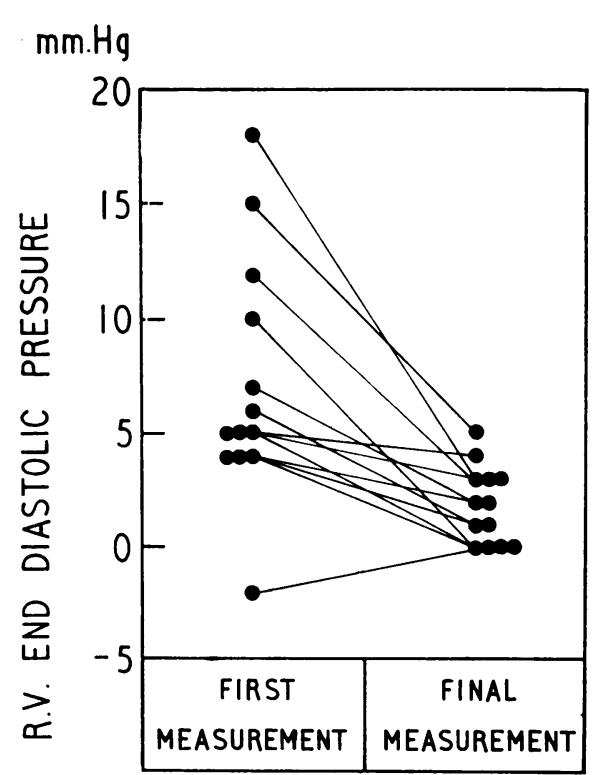

Fig. 6.-First and final measurements of right ventricular end-diastolic pressure in 13 episodes of acute myocardial infarction. 

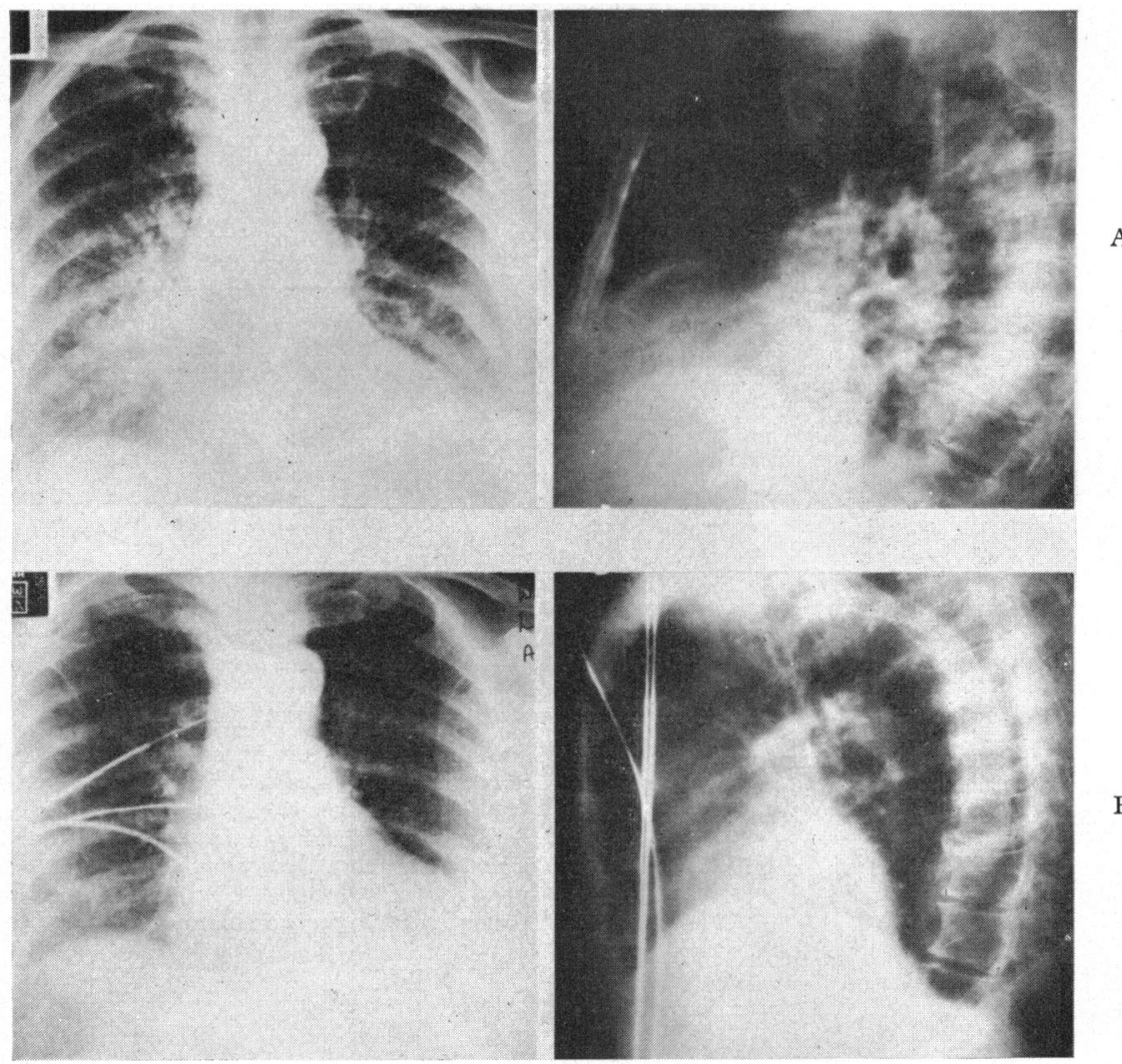

A

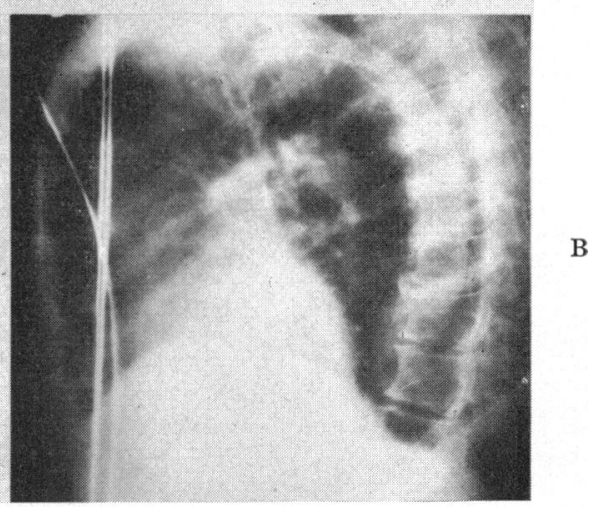

FIG. 7. - Serial chest $x$-ray films (postero-anterior and left lateral) of a patient (A) with acute pulmonary cedema on admission (2.2.66). (B) Complete resolution of pulmonary odema 2 days later (4.2.66).

In 8 the most marked reduction in arterial $\mathrm{O}_{2}$ tension occurred on the day of admission (Fig. 9) but in the rest it usually reached its lowest level a day or so later. The arterial oxygen tension then tended to return to around normal over the next 2 to 4 weeks. In 2 patients associated chronic bronchitis was another factor causing a reduction in arterial oxygen tensions.

Cardiac Output and Stroke Volume. Serial measurements of resting cardiac output and stroke volume were made in 7 patients (Table). In the series as a whole the stroke volume varied between $21 \mathrm{ml}$. and $76 \mathrm{ml}$. and the cardiac output between 2.5 and $5.51 . / \mathrm{min}$. The $\mathrm{O}_{2}$ consumption ranged from 171 to $278 \mathrm{ml} . / \mathrm{min}$. In general, a change in cardiac output was reflected by reciprocal change in arteriovenous $\mathrm{O}_{2}$ content difference, the $\mathrm{O}_{2}$ consumption remaining little altered.

Five of the 7 patients had serial resting cardiac outputs within the lower range of normal (Cases 1, $3,4,5$, and 6 ). In these the stroke volume was also normal or only slightly reduced, except in 1 patient with marked sinus tachycardia (Case 3, Table). In the other 2 patients (Cases 2 and 7) the resting cardiac output was found to be low initially ( 3.0 and $2 \cdot 81$./min., respectively) and was associated with a small stroke volume (27 and $23 \mathrm{ml}$.).

Clinical Features. All patients were routinely nursed in the horizontal position, in order to maintain the systemic blood pressure, and most patients, even in the presence of radiological pulmonary œdema, were comfortable lying flat. Three of the 9 patients, however, with more marked pulmonary œdema, were orthopnœic and had to be nursed sitting up.

In nearly all patients the respiratory rate was found to be raised (20-42 breaths/min.) during the acute phase of the infarct. Some correlation was seen between a rise in the respiratory rate and the presence of pulmonary œdema radiologically.

A few posterior basal crepitations were a common physical sign, but widespread crepitation occurred 


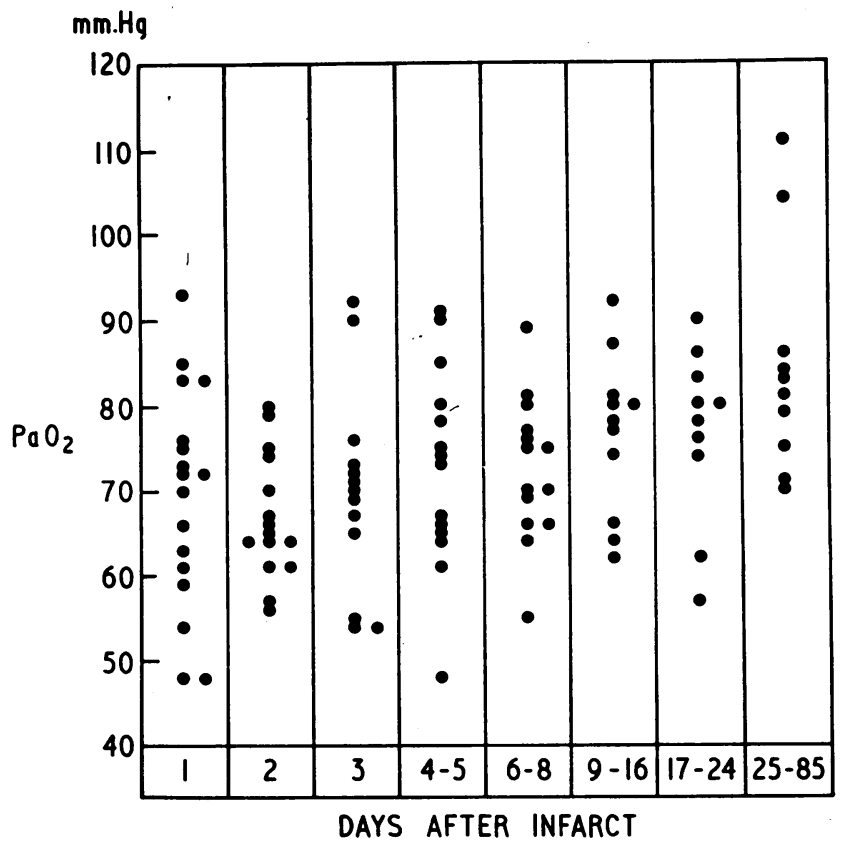

FIG. 8.-Serial $\mathrm{P}_{\mathrm{a}} \mathrm{O}_{2}$ estimations in 20 episodes of acute myocardial infarction for up to 3 months after the infarct. Measurements were made daily as far as possible for the first 3 days and after that at weekly intervals for the first month, with one subsequent reading in selected patients.

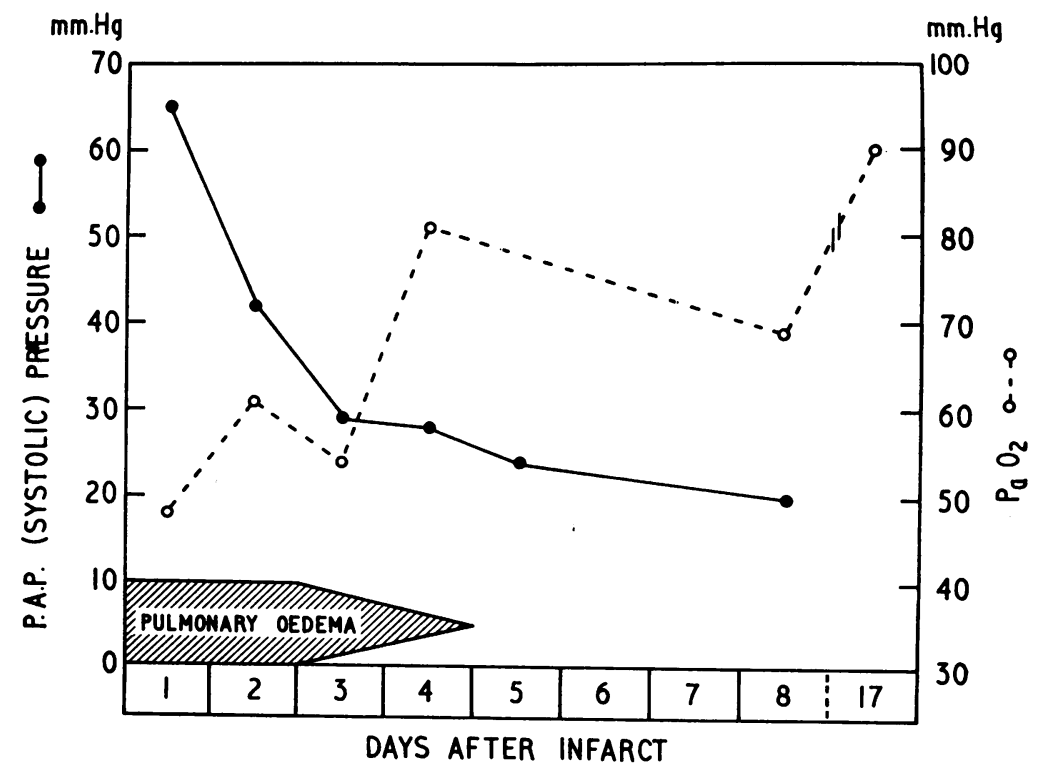

FIG. 9.-Serial measurements of pulmonary arterial systolic pressure and $\mathrm{P}_{\mathrm{a}} \mathrm{O}_{2}$, related to resolution of pulmonary odema on chest $x$-ray film, on one patient. 
TABLE

CARDIAC OUTPUT AND STROKE VOLUME IN 7 PATIENTS

\begin{tabular}{|c|c|c|c|c|c|c|c|c|c|c|}
\hline $\begin{array}{l}\text { Case } \\
\text { No. }\end{array}$ & Days & $\frac{\text { PAP太 }}{\left(\mathbf{m m} . \mathbf{H g}^{\prime}\right)}$ & $\begin{array}{c}\text { Oxygen } \\
\text { venous } \\
\text { saturation } \\
(\%)\end{array}$ & $\begin{array}{c}\text { Arterial } \\
\text { oxygen } \\
\text { saturation } \\
(\%)\end{array}$ & $\begin{array}{l}\text { Oxygen } \\
\text { A-V diff. } \\
\text { (ml. \%) }\end{array}$ & $\begin{array}{c}\text { Oxygen } \\
\text { consumption } \\
\text { (ml./min. } \\
(\text { STPD)) }\end{array}$ & $\begin{array}{c}\text { Cardiac } \\
\text { output } \\
(1 . / \mathrm{min} .)\end{array}$ & $\begin{array}{c}\text { Heart } \\
\text { rate } \\
\text { (beat/min.) }\end{array}$ & $\begin{array}{l}\text { Stroke } \\
\text { vol. } \\
\text { (ml.) }\end{array}$ & Rhythm \\
\hline 1 & $\begin{array}{l}1 \\
3\end{array}$ & $\begin{array}{l}32 \\
24\end{array}$ & $\begin{array}{l}71 \\
69\end{array}$ & $\begin{array}{l}93 \\
96\end{array}$ & $\begin{array}{l}4 \cdot 6 \\
5 \cdot 4\end{array}$ & $\begin{array}{l}233 \\
206\end{array}$ & $\begin{array}{l}5 \cdot 1 \\
3.9\end{array}$ & $\begin{array}{l}84 \\
84\end{array}$ & $\begin{array}{l}61 \\
46\end{array}$ & $\begin{array}{l}\text { SR } \\
\text { SR }\end{array}$ \\
\hline 2 & $\begin{array}{l}1 \\
3\end{array}$ & $\begin{array}{l}45 \\
24\end{array}$ & $\begin{array}{l}65 \\
59\end{array}$ & $\begin{array}{l}98 \\
98\end{array}$ & $\begin{array}{l}6 \cdot 7 \\
7 \cdot 9\end{array}$ & $\begin{array}{l}200 \\
222\end{array}$ & $\begin{array}{l}3 \cdot 0 \\
2 \cdot 8\end{array}$ & $\begin{array}{r}110 \\
92\end{array}$ & $\begin{array}{l}27 \\
31\end{array}$ & $\begin{array}{l}\text { SR } \\
\text { SR }\end{array}$ \\
\hline 3 & $\begin{array}{l}2 \\
3 \\
6\end{array}$ & $\begin{array}{l}50 \\
48\end{array}$ & $\begin{array}{l}63 \\
58 \\
60\end{array}$ & $\begin{array}{l}92 \\
89 \\
88\end{array}$ & $\begin{array}{l}6 \cdot 0 \\
6 \cdot 5 \\
4 \cdot 8\end{array}$ & $\begin{array}{l}240 \\
243 \\
278\end{array}$ & $\begin{array}{l}4 \cdot 0 \\
3 \cdot 7 \\
5 \cdot 8\end{array}$ & $\begin{array}{r}116 \\
114 \\
92\end{array}$ & $\begin{array}{l}35 \\
33 \\
63\end{array}$ & $\begin{array}{l}\text { SR } \\
\text { SR } \\
\text { SR }\end{array}$ \\
\hline 4 & $\begin{array}{l}1 \\
2 \\
6\end{array}$ & $\begin{array}{l}24 \\
23 \\
15\end{array}$ & $\begin{array}{l}63 \\
57 \\
68\end{array}$ & $\begin{array}{l}93 \\
92 \\
95\end{array}$ & $\begin{array}{l}5 \cdot 0 \\
5 \cdot 6 \\
4 \cdot 3\end{array}$ & $\begin{array}{l}227 \\
213 \\
203\end{array}$ & $\begin{array}{l}4 \cdot 6 \\
3 \cdot 8 \\
4 \cdot 9\end{array}$ & $\begin{array}{l}60 \\
68 \\
76\end{array}$ & $\begin{array}{l}76 \\
56 \\
65\end{array}$ & $\begin{array}{l}\text { SR } \\
\text { SR } \\
\text { SR }\end{array}$ \\
\hline 5 & $\begin{array}{r}1 \\
2 \\
3 \\
24\end{array}$ & $\begin{array}{l}28 \\
26 \\
24 \\
24\end{array}$ & $\begin{array}{l}68 \\
58 \\
60 \\
73\end{array}$ & $\begin{array}{l}91 \\
91 \\
93 \\
96\end{array}$ & $\begin{array}{l}4 \cdot 8 \\
5 \cdot 7 \\
5 \cdot 8 \\
4 \cdot 4\end{array}$ & $\begin{array}{l}204 \\
258 \\
232 \\
200\end{array}$ & $\begin{array}{l}4 \cdot 3 \\
4 \cdot 6 \\
3 \cdot 9 \\
4 \cdot 5\end{array}$ & $\begin{array}{l}70 \\
84 \\
74 \\
67\end{array}$ & $\begin{array}{l}61 \\
54 \\
53 \\
68\end{array}$ & $\begin{array}{l}\text { SR } \\
\text { SR } \\
\text { SR } \\
\text { SR }\end{array}$ \\
\hline 6 & $\begin{array}{r}1 \\
4 \\
11\end{array}$ & $\begin{array}{l}32 \\
26\end{array}$ & $\begin{array}{l}58 \\
71 \\
72\end{array}$ & $\begin{array}{l}83 \\
93 \\
95\end{array}$ & $\begin{array}{l}5 \cdot 5 \\
5 \cdot 0 \\
4 \cdot 9\end{array}$ & $\begin{array}{l}279 \\
275 \\
228\end{array}$ & $\begin{array}{l}5 \cdot 1 \\
5 \cdot 5 \\
4 \cdot 7\end{array}$ & $\begin{array}{r}80 \\
100 \\
78\end{array}$ & $\begin{array}{l}64 \\
55 \\
60\end{array}$ & $\begin{array}{l}\text { SR } \\
\text { SR } \\
\text { SR }\end{array}$ \\
\hline 7 & $\begin{array}{r}1 \\
2 \\
3 \\
5 \\
21\end{array}$ & $\begin{array}{l}83 \\
38 \\
65 \\
53 \\
50\end{array}$ & $\begin{array}{l}55 \\
71 \\
72 \\
60 \\
63\end{array}$ & $\begin{array}{l}89 \\
97 \\
99 \\
97 \\
97\end{array}$ & $\begin{array}{l}6 \cdot 6 \\
5 \cdot 2 \\
5 \cdot 6 \\
7 \cdot 3 \\
5 \cdot 2\end{array}$ & $\begin{array}{l}182 \\
197 \\
171 \\
183 \\
200\end{array}$ & $\begin{array}{l}2.8 \\
3.8 \\
3.1 \\
2.5 \\
3.9\end{array}$ & $\begin{array}{r}120 \\
76 \\
122 \\
120 \\
100\end{array}$ & $\begin{array}{l}23 \\
49 \\
25 \\
21 \\
39\end{array}$ & $\begin{array}{l}\text { SR } \\
\text { SR } \\
\text { AF } \\
\text { AF } \\
\text { SR }\end{array}$ \\
\hline
\end{tabular}

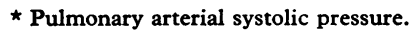

in only 11 of the 27 episodes of infarction. Almost all patients had a persisting fourth sound, but a transient third sound was present in only four.

\section{Discussion}

Cause of Raised Pulmonary Arterial Pressure. In this study approximately 80 per cent of the patients had a rise of pulmonary arterial pressure after an acute cardiac infarct, which tended to settle during the first week. Important factors responsible for the rise in pulmonary arterial pressure could be a raised left atrial pressure, increased pulmonary vascular resistance, a rise in cardiac output, or a combination of these. Cardiac output determinations were made in 7 patients, in 5 of whom the pulmonary arterial pressure was high on admission. In none of these was the cardiac output higher than $5 \cdot 11 . / \mathrm{min}$. In addition, the patient with the highest pulmonary arterial systolic pressure $(83 \mathrm{~mm} . \mathrm{Hg}$ ) was found to have the lowest cardiac output $(2 \cdot 8$ 1./min.) and stroke volume $(23 \mathrm{ml}$.). It seems unlikely, therefore, from this evidence that a raised cardiac output or stroke volume was responsible for the increased pulmonary arterial pressure in the series as a whole.

Turning to the possibility that either an increase in left atrial pressure or in pulmonary vascular resistance could be responsible for the raised pulmonary arterial pressure, we were unable in this study to measure pulmonary wedge pressure with the
PE60 catheter. Collateral evidence of pulmonary œdema in the chest $x$-ray film strongly supported the concept of a raised left ventricular end-diastolic pressure as the cause of the transient pulmonary hypertension in 9 patients. Its cause, however, was less certain where there was no pulmonary œdema. There is a considerable body of evidence to show that a transient rise in both left ventricular end-diastolic and pulmonary arterial pressure occurs in some patients during angina pectoris, whether spontaneous or on effort (Müller and Rørvik, 1958; Johnson, Fairley, and Carter, 1959; Ross et al., 1962; Dimond and Benchimol, 1963; Malmborg, 1965; Cohen et al., 1965; Parker, Di Giorgi, and West, 1966; Roughgarden, 1966). If the acute hæmodynamic changes in angina parallel to some degree those seen in cardiac infarction, this might suggest that a rise in left ventricular end-diastolic pressure is the main factor causing transient pulmonary hypertension in acute cardiac infarction.

Hypoxia is a well-recognized cause of pulmonary hypertension (Motley et al., 1947; Fritts et al., 1960), and the possibility that this might have been a contributory factor in the rise in pulmonary arterial pressure in our series had therefore to be considered. When breathing air the hypoxia in our patients was mild, the $\mathrm{P}_{\mathrm{a}} \mathrm{O}_{2}$ rarely falling below $60 \mathrm{~mm}$. $\mathrm{Hg}$ and never below $45 \mathrm{~mm}$. Hg. Moreover, the pulmonary arterial pressure usually returned to normal in a few days, whereas the $\mathrm{P}_{\mathrm{a}} \mathrm{O}_{2}$ 
remained reduced for several weeks. Nor did the change from breathing air to breathing 100 per cent oxygen by mask at $6 \mathrm{l} . / \mathrm{min}$. in one patient do more than slightly reduce by a few $\mathrm{mm}$. $\mathrm{Hg}$ a high pulmonary arterial pressure. Thus, it is unlikely that hypoxia was responsible to any significant degree for the raised pulmonary arterial pressure in our series.

Relation between Pulmonary Arterial Pressure, Pulmonary Edema, and $P_{a} o_{2}$. In the patients with radiological pulmonary œdema the pulmonary arterial pressure was above normal in all, though raised pulmonary arterial pressures were also found in many of the patients without œdema (Fig. 10). The 2 patients with the highest pulmonary arterial pressure both had pulmonary odema. During the resolution of pulmonary odema, the pulmonary arterial pressure tended to return to normal first, a day or so before the radiological evidence of pulmonary œdema cleared (Fig. 9). The last measurement to return to normal was the $\mathrm{P}_{\mathrm{a}} \mathrm{O}_{2}$, several weeks after the radiological evidence of pulmonary œedema had cleared. B. E. Heard, R. E. Steiner, A. Herdon, and D. C. Gleason (1967, unpublished observations) have shown, in acute pulmonary œdema, that because of organization of the fibrinous exudate, complete resolution is delayed for several weeks, an observation that might explain the slow return to normal of the $\mathrm{P}_{\mathrm{a}} \mathrm{O}_{2}$ in patients in our series and in those of Valentine et al. (1966) and McNicol et al. (1966).

Relation between Right Ventricular End-diastolic Pressure and Pulmonary Arterial Pressure. Approximately half the patients were found to have a right ventricular end-diastolic pressure above $5 \mathrm{~mm}$. $\mathrm{Hg}$, when first measured. With 3 exceptions, all patients with a raised right ventricular end-diastolic pressure initially had also a raised right ventricular systolic pressure. In general, as the pulmonary arterial pressure fell to normal during the first week there was an accompanying fall in the right ventricular end-diastolic pressure from the levels recorded on admission (Fig. 11). In 3 patients the right ventricular end-diastolic pressure was raised disproportionately to any change in pulmonary arterial pressure, right ventricular end-diastolic pressure measuring 12,10 , and $8 \mathrm{~mm}$. $\mathrm{Hg}$ while the pulmonary arterial pressure measured 28, 24, and 30 $\mathrm{mm} . \mathrm{Hg}$, respectively. It is of some interest that these 3 patients were also similar clinically, in that all belonged to the supraventricular bradycardia group (Fluck et al., 1967b), with vasovagal episodes and posterior siting of the infarct. Whether raised end-diastolic pressure in these patients may have

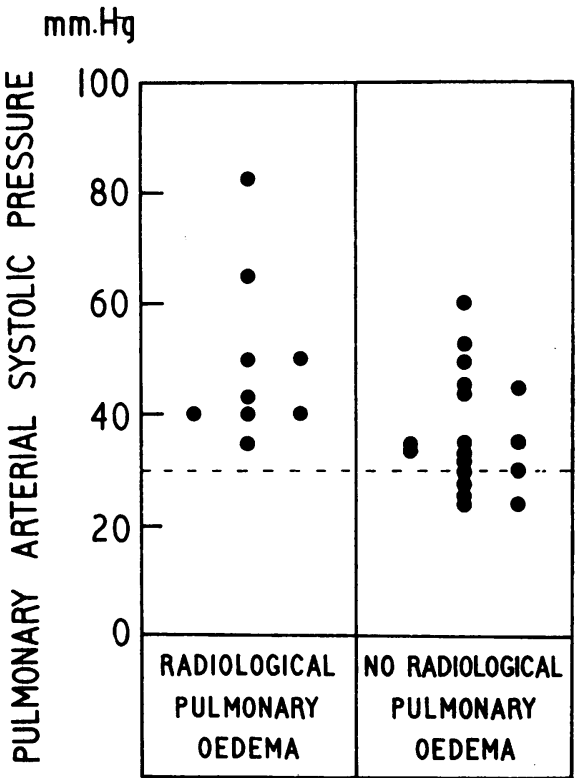

FIG. 10.-Relation between maximum pulmonary arterial systolic pressure and the presence of pulmonary œdema.

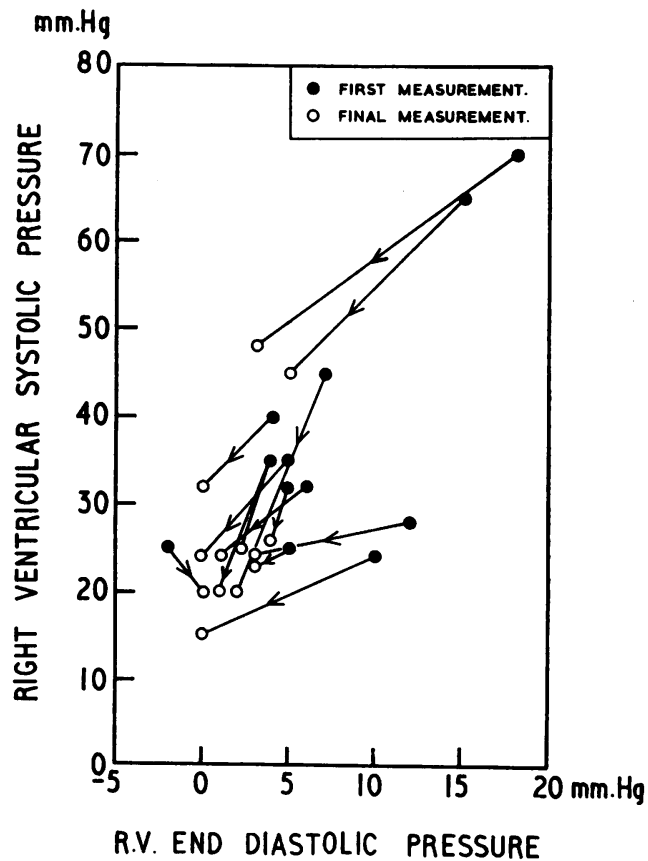

FIG. 11.-Relation between first and final measurements of right ventricular systolic and end-diastolic pressure. 
reflected involvement of the right ventricle in the process of infarction or was in some way related to the bradycardia was uncertain.

The evidence from this study suggests, therefore, that a raised right ventricular end-diastolic pressure is commonly present after an acute myocardial infarct, and that in the majority of cases this is associated with a transient rise in pulmonary arterial pressure.

Changes in Systemic Blood Pressure Relation to Pulmonary Arterial Pressure. The 8 patients whose systemic blood pressure was raised on admission had an initial rise in pulmonary arterial pressure. In 6 of them there was a fall in both systemic and pulmonary arterial pressures over the first few days after the infarct. This might suggest the influence of a common mechanism in these cases, such as a fall in cardiac output, but in the other 2 patients a fall in pressure occurred in either the systemic or pulmonary circuit without parallel changes in the other circuit.

Of the 7 patients with systemic hypotension during the first few days after the infarct, only 4 had an initial rise in pulmonary arterial pressure and these were the group with tachycardia and clinical evidence of left ventricular failure. In the remaining 3, with a tendency to sinus bradycardia and no evidence of left ventricular failure, the pulmonary arterial pressure remained normal.

There appeared, therefore, to be no over-all relation between changes in systemic blood pressure and pulmonary arterial pressure.

Relation between Pulmonary Arterial Pressure and Prognosis. The presence of a raised pulmonary arterial pressure during the acute stage of a cardiac infarct was found to be an important prognostic sign in patients with acute myocardial infarction. There were 5 deaths in 21 episodes of cardiac infarction in which the pulmonary arterial pressure was raised on admission, whereas in the remaining 6 episodes of infarction without a rise in pulmonary arterial pressure, all patients survived. Persistence of a raised pulmonary arterial pressure after the first few days of acute myocardial infarction was always associated with clinical evidence of chronic left ventricular failure.

\section{SUMMARY}

Serial right heart pressure measurements were made in 27 episodes of acute cardiac infarction.

A raised pulmonary arterial systolic pressure was found during the first few days in 21 episodes. This pressure returned to normal at the end of a week in all but 3 who remained in chronic left ventricular failure.

A parallel rise in right ventricular end-diastolic pressure was noted in most patients, which returned to normal synchronously with the pulmonary arterial systolic pressure.

Radiological evidence of pulmonary œdema was seen in 9 patients, in all of whom the pulmonary arterial pressure was raised on admission. These patients also had the greatest reduction in $\mathrm{P}_{\mathrm{a}} \mathrm{O}_{2}$. In the recovery phase, the pulmonary arterial pressure fell to normal, followed by resolution of pulmonary œdema, while the $\mathrm{P}_{\mathrm{a}} \mathrm{O}_{2}$ did not rise to normal levels until several weeks later.

The prognosis in patients with an initial rise in pulmonary arterial pressure was worse than in those in whom the pulmonary arterial pressure remained normal throughout the acute illness.

Our results suggest that left heart failure occurs more commonly in acute cardiac infarction than might be expected on clinical grounds alone. They emphasize the importance of meticulous treatment with bed-rest, oxygen, diuretics, prophylactic antibiotics, and breathing exercises in patients with pulmonary congestion and early pulmonary œdema. The technique of the float right heart catheter facilitates careful monitoring of progress and response to treatment in these acutely ill patients.

We should like to thank Professor J. P. Shillingford for his advice and help, and Mr. Peter Burgess and Miss Jean Powell for technical assistance.

\section{REFERENCES}

Cohen, L. S., Elliott, W. C., Rolett, E. L., and Gorlin, R. (1965). Hemodynamic studies during angina pectoris. Circulation, 31, 409.

Dimond, E. G., and Benchimol, A. (1963). Correlation of intracardiac pressure and præcordial movement in ischæmic heart disease. Brit. Heart f., 25, 389.

Fluck, D. C., Hughes, J. M. B., Valentine, P. A., and Mounsey, J. P. D. (1967a). Cardiopulmonary studies in Cheyne-Stokes respiration following myocardial infarction. In Proceedings of the British Cardiac Society. Brit. Heart F., 29, 631.

-, Olsen, E., Pentecost, B. L., Thomas, M., Fillmore, S. J., Shillingford, J. P., and Mounsey, J. P. D. (1967b). Natural history and clinical significance of arrhythmias after acute cardiac infarction. Brit. Heart F., 29, 170.

Fritts, H. W., Jr., Odell, J. E., Harris, P., Braunwald, E. W., and Fishman, A. P. (1960). Effects of acute hypoxia on the volume of blood in the thorax. Circulation, 22, 216.

Gleason, D. C., and Steiner, R. E. (1966). The lateral roentgenogram in pulmonary edema. Amer. F. Roentgenol., 98, 279.

Johnson, J. B., Fairley, A., and Carter, C. (1959). Effects of sublingual nitroglycerin on pulmonary arterial pressure in patients with left ventricular failure. Ann. intern. Med., 50, 34. 
McNicol, M. W., Kirby, B. J., Bhoola, K. D., Fulton, P. M.; and Tattersfield, A. E. (1966). Changes in pulmonary function 6-12 months after recovery from myocardial infarction. Lancet, 2, 1441.

Malmborg, R. O. (1965). A clinical and hemodynamic analysis of factors limiting the cardiac performance in patients with coronary heart disease. Acta med. scand., Suppl. 426.

Motley, H. L., Cournand, A., Werko, L., Himmelstein, A., and Dresdale, D. (1947). The influence of short periods of induced acute anoxia upon pulmonary artery pressures in man. Amer. F. Physiol., 150, 315.

Müller, O., and Rørvik, K. (1958). Hæmodynamic consequences of coronary heart disease with observations during anginal pain and on the effect of nitroglycerine. Brit. Heart f., 20, 302.

Parker, J. O., Di Giorgi, S., and West, R. O. (1966). A hemodynamic study of acute coronary insufficiency precipitated by exercise, with observations on the effect of nitroglycerin. Amer. F. Cardiol., 17, 470.

Ross, R. S., Schwartz, N., Gaertner, R. A., and Friesinger, G. C. (1962). Electrocardiographic and hemodynamic observations during selective coronary cineangiocardiography. F. clin. Invest., 41, 1395.

Roughgarden, J. W. (1966). Circulatory changes associated with spontaneous angina pectoris. Amer. F. Med., 41, 947.

Seldinger, S. I. (1953). Catheter replacement of the needle in percutaneous arteriography. Acta radiol. (Stockh.), 39, 368.

Valentine, P. A., Fluck, D. C., Mounsey, J. P. D., Reid, D., Shillingford, J. P., and Steiner, R. E. (1966). Bloodgas changes after acute myocardial infarction. Lancet, 2, 837 . 